\title{
SIMPLE ENDOMETRIAL HYPERPLASIA - POST TAMOXIFEN THERAPY IN A PATIENT OF CARCINOMA BREAST
}

\author{
M. Valluvan ${ }^{1}$, Divvya B2, P. Viswanathan ${ }^{3}$, Rehana Tippo ${ }^{4}$, R. Baskaran ${ }^{5}$
}

\section{HOW TO CITE THIS ARTICLE:}

M. Valluvan, Divvya B, P. Viswanathan, Rehana Tippo, R. Baskaran. "Simple Endometrial Hyperplasia - Post Tamoxifen Therapy in a Patient of Carcinoma Breast". Journal of Evolution of Medical and Dental Sciences 2014; Vol. 3, Issue 50, October 06; Page: 11856-11859, DOI: 10.14260/jemds/2014/3561

\begin{abstract}
Tamoxifen is one of the modalities in the treatment for breast cancer, especially in postmenopausal patients. It acts primarily as an anti-estrogenic agent, due to its cytoplasmic estrogen receptor binding capacity. However, the same also exerts a mild estrogenic effect. Here with a case of ER positive carcinoma breast treated with Tamoxifen for 5 years, presented as postmenopausal bleeding per vaginum, showed an enhanced mass occupying the endometrial cavity, measuring $>30 \mathrm{~mm}$ is presented. Total hysterectomy was done.
\end{abstract}

KEYWORDS: Endometrial hyperplasia, Tamoxifen therapy,

INTRODUCTION: Tamoxifen is usually classified as an estrogen antagonist as it competes with estrogens for estrogen receptors. ${ }^{1-3}$ Like clomiphene citrate, it was originally developed as a fertility agent but its main use has been in postmenopausal women with advanced breast cancer. ${ }^{2}$ Tamoxifen might exert weak estrogenic stimulation on glandular epithelium secretion, thus increasing the volume of fluid inside the glands and, therefore, their size. In contrast there is absence of any stimulatory effect on growth of the epithelium, which remains thin and atrophic. Finally, the thick and edematous stroma could be due to an estrogenic effect of Tamoxifen. The action of Tamoxifen on the human endometrium seems to be more complex than a simple estrogenic effect inducing hyperplasia.

CASE REPORT: A 58 years old postmenopausal female presented with complaints of bleeding per vaginum over a period of six months. On evaluation of history, she had undergone mastectomy for carcinoma of breast 5 years back, which showed positivity for ER, following which she was treated with Tamoxifen for the past 5 years. Ultrasonography of uterus showed hyper echoic enhancing mass measuring $>30 \mathrm{~mm}$ and distending the endometrial cavity. She was on antihypertensive treatment for past 4 years and was neither a diabetic nor a pre diabetic. The lipid profile was within normal limits.

MACROSCOPY: A proliferative growth measuring $6 \times 4.5 \mathrm{cms}$ was seen to be arising from the endometrial cavity. Surface was bosselated. Cut section showed multiple cystic structures with septae. The mass appeared to be sessile with $4 \mathrm{cms}$ base attached to the endometrium. Cobble stone appearance of the rest of the endometrium was noticed.

MICROSCOPY: The endometrial polyp showed endometrial glands which were edematous in nature and were lined by atrophic flattened cells. The endometrial glands were filled with secretory material which was protenaceous in nature. Some glands were tubular in nature and few glands are cystically dilated. Gland in gland appearance was also noticed.

DISCUSSION: The present case is of a 58 years old postmenopausal women who was under Tamoxifen treatment $30 \mathrm{mg}$ per day for the past 5 years following mastectomy done for carcinoma 


\section{CASE REPORT}

and was advised follow up with routine ultra sonographic studies to look for endometrial changes and regular serum lipid levels. The patient was advised to have gynecological examination periodically, which was ignored.

She had frequent episodes of dysfunctional uterine bleeding for the past 6 months, for which she had visited the OPD once before the surgical intervention. Routine blood investigations were normal and computed tomography showed hyper dense lesions. Histopathology examination revealed simple endometrial hyperplasia.

\section{MACROSCOPIC PICTURES:}

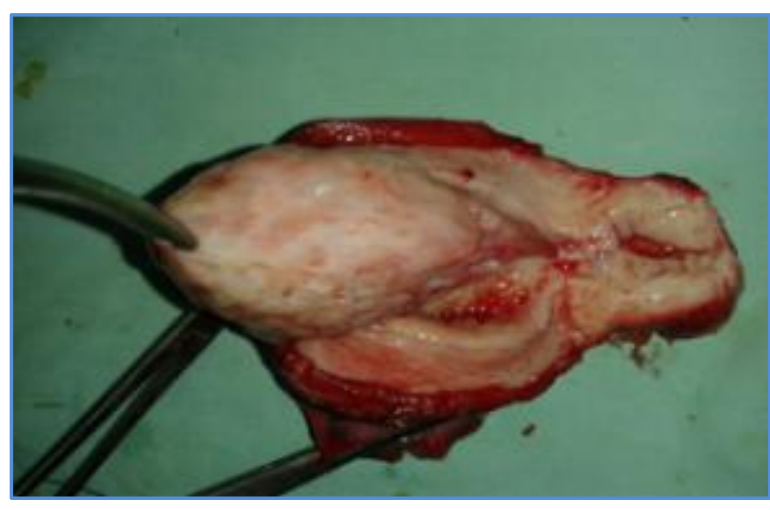

Fig. 1A post-operative specimen

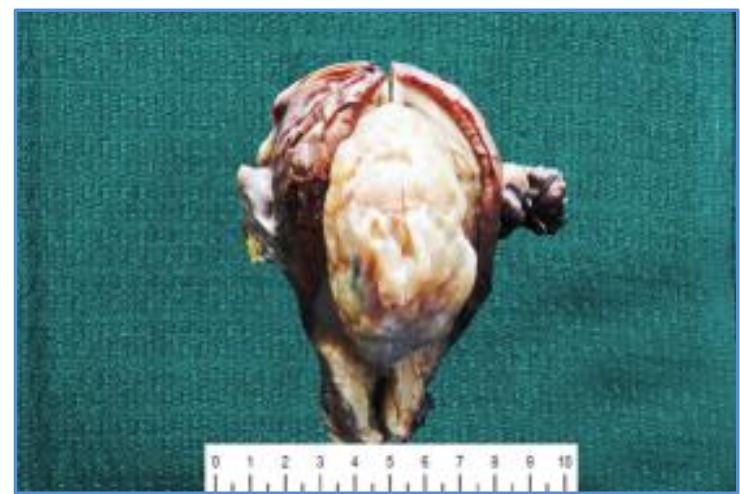

Fig. 1B Formalin fixed specimen

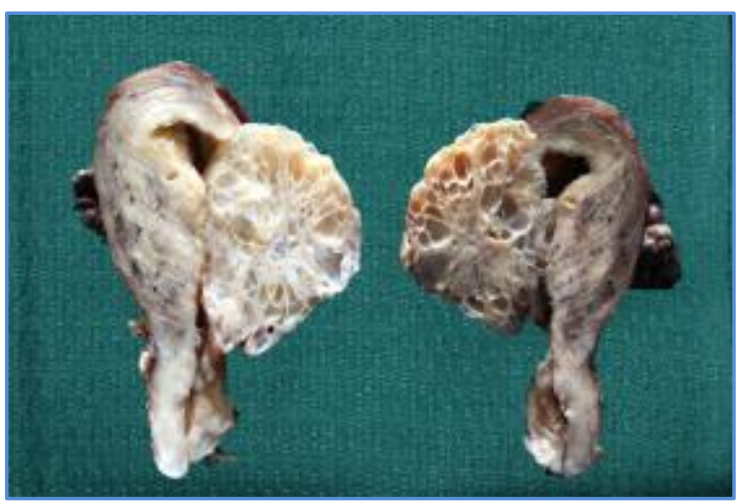

Fig. 1C (Myometrium thickened, endometrial hyperplasia seen up to endo cervix)

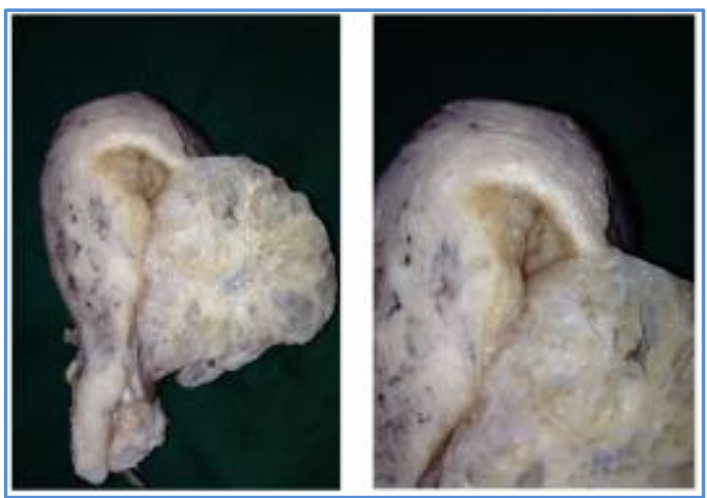

Fig. 1 D, 1E: Endometrium with cobble stone appearance 


\section{CASE REPORT}

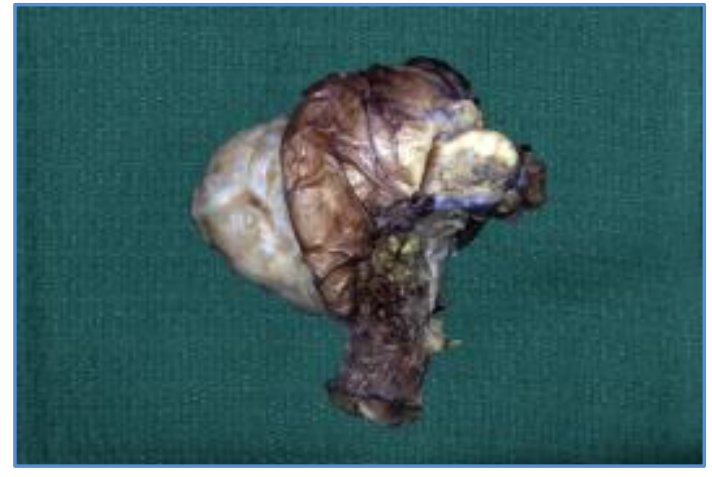

Fig. 1F

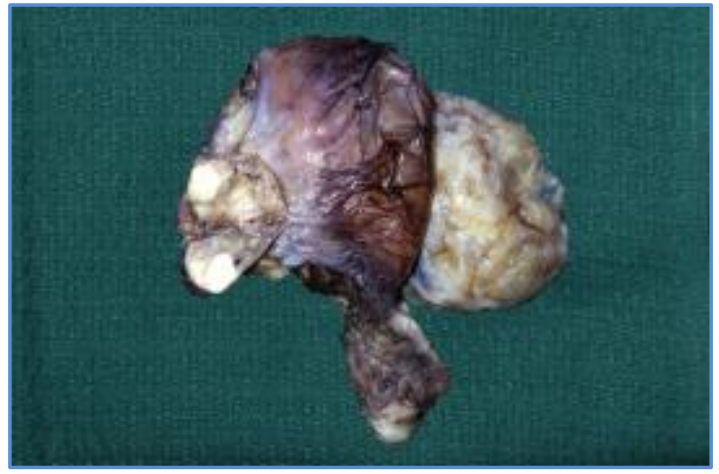

Fig. 1G

Fig. 1 (F and G): Both ovaries show corpus albican.

\section{MICROSCOPIC PICTURES:}

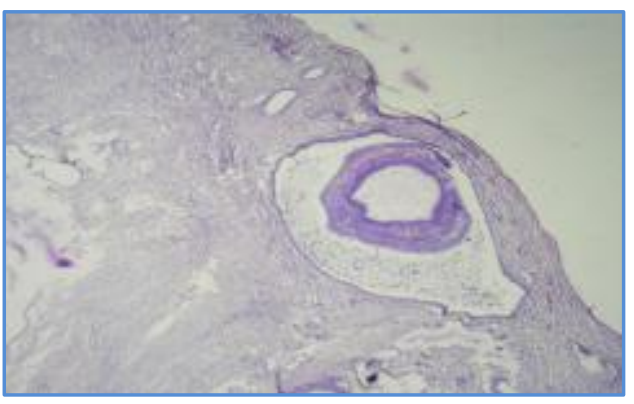

Fig. 2 (10X): Gland in gland appearance

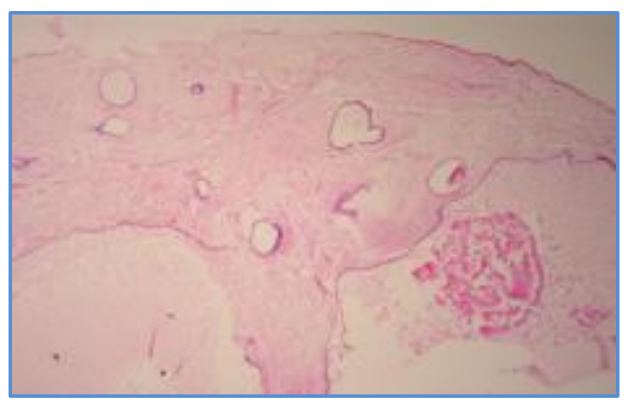

Fig. 3 (10X): Endometrium shows tubular and cystically dilated glands

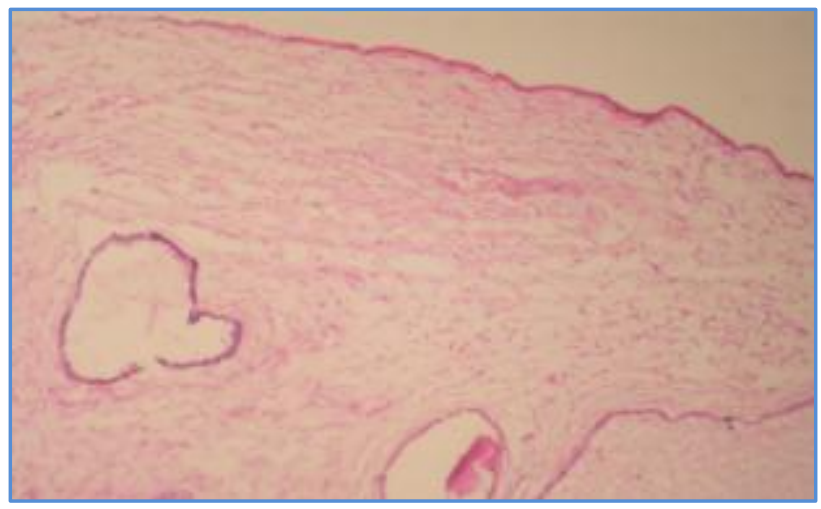

Fig. 4 (10X): Endometrium showing glands lined by flattened cells and embedded in markedly edematous stroma 


\section{CASE REPORT}

\section{REFERENCES:}

1. Cohen I, Rosen DJ, Shapiro J, Cordoba M, Gilboa S, Altaras M et al. Endometrial changes in post men opausal women treated with tamoxifen for breast cancer. Br J Obstet Gynaecol 1993; 100: 567-9.

2. Shushan A, Peretz T, Uziely B, Lewin A, Mor-Yosef S. Ovarian cysts in premenopausal and postmenopausal tamoxifen-treated women with breast cancer. Am J Obstet Gynecol 1996; 174: $141-4$.

3. Neven P, Shepherd JH, Lowe DG. Tamoxifen and gynecologist.Br J Obstet Gynaecol 1993; 100: 893-7.

\section{AUTHORS:}

1. M. Valluvan

2. Divvya B.

3. P. Viswanathan

4. Rehana Tippo

5. R. Baskaran

\section{PARTICULARS OF CONTRIBUTORS:}

1. $2^{\text {nd }}$ Year Post Graduate, Department of Pathology, Rajah Muthiah Medical College, Annamalai University, Chidambaram.

2. $2^{\text {nd }}$ Year Post Graduate, Department of Pathology, Rajah Muthiah Medical College, Annamalai University, Chidambaram.

3. Professor, Department of Pathology, Rajah Muthiah Medical College, Annamalai University, Chidambaram

4. Professor, Department of Pathology, Rajah Muthiah Medical College, Annamalai University, Chidambaram
5. Professor, Department of Surgery, Rajah Muthiah Medical College, Annamalai University, Chidambaram.

\section{NAME ADDRESS EMAIL ID OF THE CORRESPONDING AUTHOR:}

Dr. P. Viswanathan,

Professor,

Department of Pathology,

Faculty of Medicine,

Rajah Muthiah Medical College,

Annamalai University,

Chidambaram-608002,

Tamil Nadu, India.

Email: drpviswanathan2013@gmail.com

Date of Submission: 18/09/2014.

Date of Peer Review: 19/09/2014.

Date of Acceptance: 29/09/2014.

Date of Publishing: 06/10/2014. 